\title{
MARGINALIZOVANÍ JEDINCI Z VELKOMORAVSKÝCH JAMOVITÝCH OBJEKTOV V NITRE
}

\author{
Milan Hanuliak*
}

* Archeologický ústav SAV, Akademická 2, 94921 Nitra, milan.hanuliak@savba.sk.

\begin{abstract}
Marginalised individuals from the Great Moravian pit-like features in Nitra. Circumstances, which could have decided about placing of dead into the settlement features, are evaluated in the study. Their assessment is based on the sites with greater amount of features, with several individuals in their filling and with preserved proofs of violent downfall of this settlement. It is possible to ascribe main portion of untraditional inhumation to various manifestations of unusual death recalled by violence which accompanied fighting actions according to this. These circumstances contributed to the considerable marginalisation of original social status of individuals. Proscribed individuals were laid into the inferior space of settlement features as a consequence of this events. Their bodies were arranged in the flexed position, prone position, their anatomical position was disturbed by intentional intervention on behalf of protection of local community from their negative influence.
\end{abstract}

Keywords: Slovakia, Great Moravian period, settlement feature, unconventional inhumation, war actions

Abstrakt: V príspevku sa vyhodnocujú okolnosti, ktoré mohli rozhodovat’ o umiestňovaní zomrelých do sídliskových objektov. Pri posudzovaní sa vychádzalo z lokalít s väčším počtom objektov, s viacerými jedincami v ich výplni a zachovanými dokladmi násilného zániku tamojšieho osídlenia. Podl’a toho sa dá hlavný podiel netradičnej inhumácie pripísat' rôznym prejavom neobvyklého úmrtia vyvolaného násilím, ktoré sprevádzalo bojové akcie. Tieto okolnosti prispeli k značnej marginalizácii pôvodného sociálneho postavenia jedincov. Následkom toho boli proskribovaní uložení do podradného priestoru sídliskových objektov. V záujme ochrany miestnej komunity pred ich negatívnym vplyvom boli ich telá upravené do pokrčenej polohy na boku, na bruchu, zámerným zákrokom sa porušilo ich anatomické usporiadanie.

Kl’účové slová: Slovensko, vel'komoravské obdobie, sídliskový objekt, netradičná inhumácia, bojové akcie

https://doi.org/10.46283/musarch.2020.1.05

\section{1. Úvod}

V uplynulom období pribudli k dosial' známym sídliskovým objektom s telesnými zvyškami l’udských jedincov traja reprezentanti preskúmaní na území historickej Nitry. Takto skompletizovaná kolekcia z vel’komoravského obdobia na Slovensku sa následne rozrástla na 16 lokalít s 31 objektmi a kostrovým materiálom, ktorý pochádza z viac ako 55 zomrelých (Hanuliak 2004, 38-39).

\section{Charakteristické prejavy}

K špecifickým charakteristikám tohto súboru patria jedinci rozdielneho pohlavia a veku uložení vo výraznej prevahe do zásobnicových jám. Studňovitý objekt a plytší jamovití zástupcovia patria k vzácnym výnimkám. Z tejto skutočnosti možno odvodit', že l'udskí jedinci neboli pochovaní do tradičných hrobových jám považovaných za 
posmrtný príbytok (Pollex 2000, 407), ale iba uložení do druhotriedneho náhradného priestoru, ktorý bol v danom čase na sídlisku prázdny. Aj preto sa z tohto súboru vymykajú dve obilnice, ktoré boli v rovnakom časovom rámci vyhíbené na pohrebisku v polohe Drahy z Cífera-Pácu (Zábojník 1985, obr. 2).

Zúženú skladbu pohrebných obradov potvrdzuje viacero zložiek. Z významnejších $\mathrm{k}$ nim patrí chýbajúca relevantná skladba pohrebného inventára, úprava tiel do kanonizovanej polohy ul’ahčujúca prechod zomrelých do záhrobného prostredia (Hanuliak 2011, 136-137). Nemožno takisto nevidiet’ výnimočné polohy tiel spočívajúce obvykle na boku, zriedkavejšie na bruchu, ojedinele aj s vykrúteným telom na chrbte a pokrčenými končatinami (Hanuliak 1997, obr. 5: 1, 3; 6: 1). Postrehnutú rôznorodost' umocňuje nadmerný rozptyl azimutov orientácie odklonených od rituálnej západnej línie nasmerovanej do predkrest’anského záhrobia. Ak sa následne pripoja chýbajúce predmety pohrebného inventára, nachádzané prednostne $\mathrm{v}$ regulárnych hroboch u jedincov istého pohlavia veku (porovnaj: Hanuliak 1997, tab. I: 3, 5, 6, 8-10), sformuje sa ucelená názorová predstava.

Podl'a nej nemohlo íst' o náhodu, ked' sa pri posmrtnom zaopatrovaní zosnulých nevykonali tradičné pohrebné obrady. Nejde pritom o bezvýznamný nedostatok, pretože predmetné zložky mali bezúhonným jedincom zabezpečit' rovnakú posmrtnú existenciu ako v pozemskom živote. $\mathrm{V}$ analyzovanom fonde sa naopak nedajú prehliadnut' aktivity, ktoré mali zomrelým zabránit' úspešný prechod na „onen svet“ a st’ažit' pokojnú existenciu v novom prostredí. Okrem uprednostnenia nehrobového objektu zo sídliskového nie pohrebiskového prostredia sa dajú za smerodajné označit' aj nezvyčajné polohy tiel, ktoré by sotva vznikli bez konkrétneho zámeru.

V súlade s identickými prejavmi doloženými v pohrebiskovom prostredí boli aj zosnulí zo sídliskových objektov stotožňovaní s podozrivými a nebezpečnými indivíduami. Podla toho im taktiež mali byt' pripisované schopnosti poškodzujúce miestnu komunitu. I preto muselo dôjst' k eliminovaniu negatívnych skutočností pomocou už osvedčených obranných praktík (Hanuliak 2004, 38-39). V podstate išlo o využitie obmedzeného registra dostupných manuálne aplikovatel'ných obranných mechanizmov s pripisovanou schopnost'ou likvidovat' všadeprítomné škodlivé účinky najrôznejšieho druhu. A takéto zákroky sa častokrát nesprávne spájajú s tzv. protivampirickými aktivitami novovekej proveniencie (Krumphanzlová 1964, 178-179; 1971, 415; Maielo 2014, 15-58, 113-132). K podpore tohto názoru by s určitost'ou prispeli aj d’alšie v zhmotnenej podobe nezachované sprievodné skutočnosti vrátane gest, slovných zaklínadiel, ktoré $\mathrm{v}$ záujme obrátenia zla $\mathrm{k}$ dobru akiste sprevádzali aj takéto výnimočné prípady manipulácie s telami niektorých zomrelých.

\section{Prejavy marginalizácie}

Nemožno prehliadnut', že sa s predchádzajúcou zovšeobecňujúcou interpretáciou zhodnocovaných prejavov nestotožňujú nálezové okolnosti zo všetkých sídliskových objektov. Presvedčivejšie v tomto smere vyznievajú zástupcovia lokalít s viac ako jedným súvekým objektom, reprezentanti so spoločným výskytom viacerých jedincov v jeho výplni, ako aj prípady s postmortálne dezartikulovaným kostrovým materiálom presunutým druhotne do jamovitých priehlbní prevrstveným deštrukčným odpadom. Ich vznik by sa mohol súčasne stotožnit’ so snahou o nenáročnú asanáciu účastníkov vojenských stretov patriacich k nepriatel'ským či domácim bojovníkom (Hanuliak 2004, 39; Unger 2008, 129). Ked’že sa takého akcie neviedli iba v priamom strete ozbrojených účastníkov na konkrétnom bojisku, ale na ovel’a širšom území vrátene postupových trás nepriatel'ských oddielov, treba skupinu postihnutých rozšírit' o obete $\mathrm{z}$ radov miestnych obyvatel'ov.

Archeologické pramene nie sú natol’ko informatívne, aby prispeli k jednoznačnému oddeleniu zástupcov z uvedených kategórií. Vzhl’adom k skladbe určujúcich prejavov by sa nemalo pochybovat’ o marginalizácii niekdajšieho sociálneho statusu jedincov, ktorí museli byt' posmrtne uložení pertraktovaným spôsobom. Zo známych prípadov možno na ilustráciu uviest' sedem dospelých mužov z objektu AI/5 na Ventúrskej ulici v bratislavskom Starom Meste (obr. 1: 1). Ich nehybné telá boli postupne vhadzované do spodnej časti studňovitého objektu. Aj ked' čitatelnost' nálezovej situácie skomplikovalo budovanie základového úseku stredovekého muriva, nemohol stavebný zásah ako jediný prispiet’ $\mathrm{k}$ osamotenému výskytu lebiek, nekompletných postkraniálnych skeletov umiestnených $\mathrm{v}$ bočnej pozícii po obvode jamy s ohnutými až pokrčenými končatinami. Známe sú aj oddelené časti končatín pozostávajúce z jednej alebo dvoch súbežných kostí. Do zásypovej zeminy sa primiešala zániková sídlisková vrstva doplnená uhlík- 


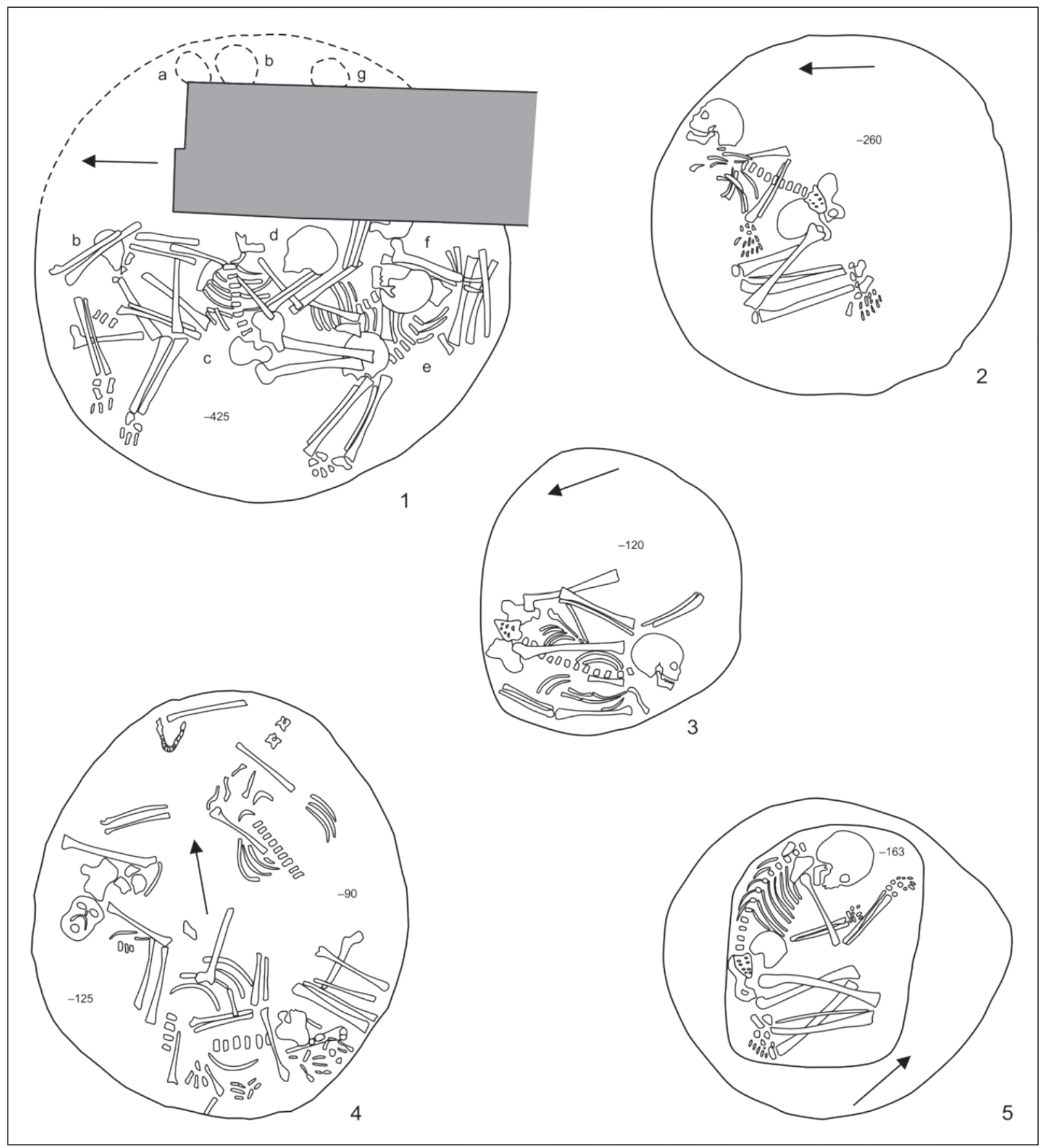

Obr. 1. 1 - Bratislava-Staré Mesto (Ventúrska ulica, objekt AI/5, podl’a Vallašek 1972, 241, obr. 3); 2-5 - MužlaČenkov (Vilmakert; 2 - objekt 71; 3 - objekt 489; 4 - objekt 726; 5 - objekt 297, podl'a Hanuliak 1997, obr. 4).

Fig. 1.1 - Bratislava-Staré Mesto (Ventúrska ulica, feature AI/5, acording Vallašek. 1972, 241, fig. 3); 2-5 - MužlaČenkov (Vilmakert; 2 - feature 71; 3 - feature 489; 4 - feature 726; 5 - feature 297, acording Hanuliak 1997, fig. 4).

mi, popolom, kameňmi, zvieracími kost’ami a sekerovitými hrivnami (Vallašek 1972, 247-248).

Ak je nálezová situácia správne zdokumentovaná mohli byt’ do tohto objektu v rýchlom slede vhadzované nekompletné, viac či menej rozčlenené časti tiel zomrelých. Vzhl’adom k tomu, že patrili mužským jedincom mladšieho veku s robustnejšou telesnou konštrukciou išlo akiste o bojovníkov, ktorí zahynuli v areáli podhradskej osady sformovanej pod východným úpätím návršia s vel’komoravským hradiskom. Z polôh zachovaných ostatkov sa dá zasa vyčítat' marginalizovaná pozícia uhynutých bez preukázatel’ného vzt’ahu k miestnym obyvatel’om.

Ak by naopak takáto väzba existovala, využili by pozostalí, podl’a predpokladu, pietnejší prístup v umiestnení 
nebožtíkov. Podobné konzekvencie by sa dali takisto pripísat' trom zomrelým z obilnej zásobnice preskúmanej na ned’alekej Panskej ulici (Lesák - Musilová 1999, 55-58). S istou dávkou rezervy by sa títo zástupcovia mohli pripojit' $\mathrm{k}$ variantom masových hrobov výnimočne zastúpených na území Slovenska.

$\mathrm{S}$ odlišnými prejavmi marginalizácie sa stretávame $\mathrm{v}$ prípadoch $\mathrm{s}$ pestrejšou skladbou zomrelých. $\mathrm{V}$ objekte 2 z polohy Jakubské B vo Velkom Cetíne sa napríklad odkryla osamotená lebka detského jedinca ležiaca v blízkosti vystretého skeletu nedospelého jedinca prekrytého nekompletnými zvyškami dospelej ženy v pokrčenej pozícii (Cheben - Ruttkayová - Ruttkay, M. 1994, 202; Hanuliak 1997, obr. 8: 2). Príbuzné prejavy sú známe z objektu 4/7 v polohe Drahy z Cífera-Pácu, v ktorom bol uložený dospelý muž oddelený vrstvou zeminy od tela dospelej ženy. Rovnaký postup bol dodržaný vo vedlajšej obilnici 32, kde išlo o dospelého muža a tri ženy (Zábojník 1985, 205-216; obr. 9 ). Skladba i pietne aplikovaný systém deponových osôb z dvoch spomenutých nálezísk signalizuje ich prepojenie s miestnymi komunitami. Z nálezových okolností sa však nedá odvodit’ intenzita ich marginalizácie ani príčiny a okolnosti jej vzniku.

Prijatel'nou informačnou hodnotou disponujú štyri obilné zásobnice zo sídliska v Šali-Veči. Z prvej z nich pochádza skelet psa, v dvoch d’alších išlo o dospelé osoby ženského pohlavia zámerne upravené do vystretej polohy na bruchu, resp. do polohy na chrbte s extrémne pokrčenými končatinami. Do poslednej obilnice boli presunuté dokonale rozpojené kosti dospelej osoby nájdené v rozptýlenej polohe (Toč́k 1992, 205-208, obr. 140-142). Vzhl’adom k obmedzenej vel'kosti sídliska, jeho krátkodobej existencii a štruktúre zásypového materiálu poukazujú takto deponovaní jedinci na jednorazovú násilnú akciu, nie na postupné a príležitostne vykonávané aktivity.

Konkrétnejšie informácie s podobným výsledným efektom sa získali z opevneného sídliska v Mužli-Čenkove, ktoré bolo začiatkom 10. stor. prepadnuté a vyplienené vojenskými oddielmi mad’arského etnika sídliaceho na susediacom zadunajskom území. Počas tejto akcie boli odstránení príslušníci miestnej elity. K nim patrila aj nedospelá žena z hrobu 23 vyhíbenom na občinovej nekropole. $K$ jej úmrtiu prispel šíp s romboidným hrotom vstrelený do bedrového stavca (Hanuliak - Kurma - Kolena 2012, 72, 74).

Počas spomenutej udalosti zrejme uhynulo aj d’alších 11 jedincov umiestnených neskôr do deviatich vyprázdnených obilníc. Išlo o členov miestnej komunity, ked’že sa po ich pričlenení k jedincom z regulárnych hrobov skorigovala pôvodne nevyvážená demografická skladba populácie. S výnimkou násilne vyrazených rezákov u dospelej ženy z objektu 489 sa na ich kostiach nezaznamenali stopy po bodno-sečných ani úderových poraneniach. Je však možné, že boli poškodené iba mäkké tkanivá, niektoré vnútorné orgány či cievny systém (Droz̨dová - Parma - Unger 2005, 171). Ich dôsledky s neskorším septickým procesom nevyvolali okamžité úmrtie, ale neskoršie skonávanie postihnutých. Tieto okolnosti sa môžu stotožnit’ so širšou škálou prejavov tzv. „,nečistej smrti“. Jej podstata, širšie rozpracovaná v novovekých písomných a etnologických prameňoch (Bednárik 1939, 86; van Dülmen 1999, 83-106; Jágerová 2001, 25), predstavuje samovol’ný spínač iniciujúci marginalizáciu sociálneho postavenia zomrelých z akejkol'vek spoločenskej vrstvy.

Osobitú súčast' ukladania zomrelých do nehrobových jám tvoria výnimočné polohy tiel. Z nich sa dá vyčítat' vzt’ah marginalizovaných $\mathrm{k}$ príslušníkom miestnej komunity, ktorí mali pádny dôvod $\mathrm{k}$ úprave tiel do obranných polôh pripomínajúcich súčasne pietnejšie vnímané podoby posmrtného spánku (obr. 1: 2). Do dna čenkovského objektu 297 bola dokonca zahíbená plytká hrobová jama, do ktorej bolo vtesnané pokrčené telo nedospelej ženy (obr. 1: 5). Skryté naopak zostávajú prićciny, pre ktoré nebola dospelá žena v objekte 489 s poddimenzovanou plochou položená na bok, ale na brucho. A to aj napriek tomu, že jej dolné končatiny museli byt' násilne nahor vykrútené a preklopené ponad chrbtovú stranu (obr.1:3).

Predchádzajúce zdôvodnenie zaznamenaných anomálií vyznieva vcelku prijatel’ne aj bez zdokladovania somatických zvláštností a perimortálnych poranení. Doložit', ale ani vylúčit' sa nedá prípadné zhanobenia tohto ludského segmentu čenkovskej komunity. Nejde o náhodu, ked’že významný diel v jeho zostave patrí nedospelým a dospelým osobám ženského pohlavia. Deti staršieho veku sú zriedkavé, dospelý muž zasa výnimočný (Hanuliak - Kuそ̌ma 2015, 126-128, 327).

Menej informatívne údaje ponúkajú nálezové okolnosti zaznamenané v objekte 726 . Ak sú zdokumentované okolnosti správne pochopené museli byt' telá nedospelej a dospelej ženy, uložené spočiatku v dvoch rozdielnych híbkových úrovniach a až neskôr porušené druhotným výkopom. Počas neho došlo $\mathrm{k}$ definitívnemu rozrušeniu anatomicky uložených telesných zvyškov. Viaceré kosti z trupu, končatín vrátane lebiek sa z výplne zásobnej jamy odstránili (Hanuliak - Kuæma - Kolena 2012, 77). Potvrdené kontinuálne napredujúce osídlenie areálu spochybňuje, 


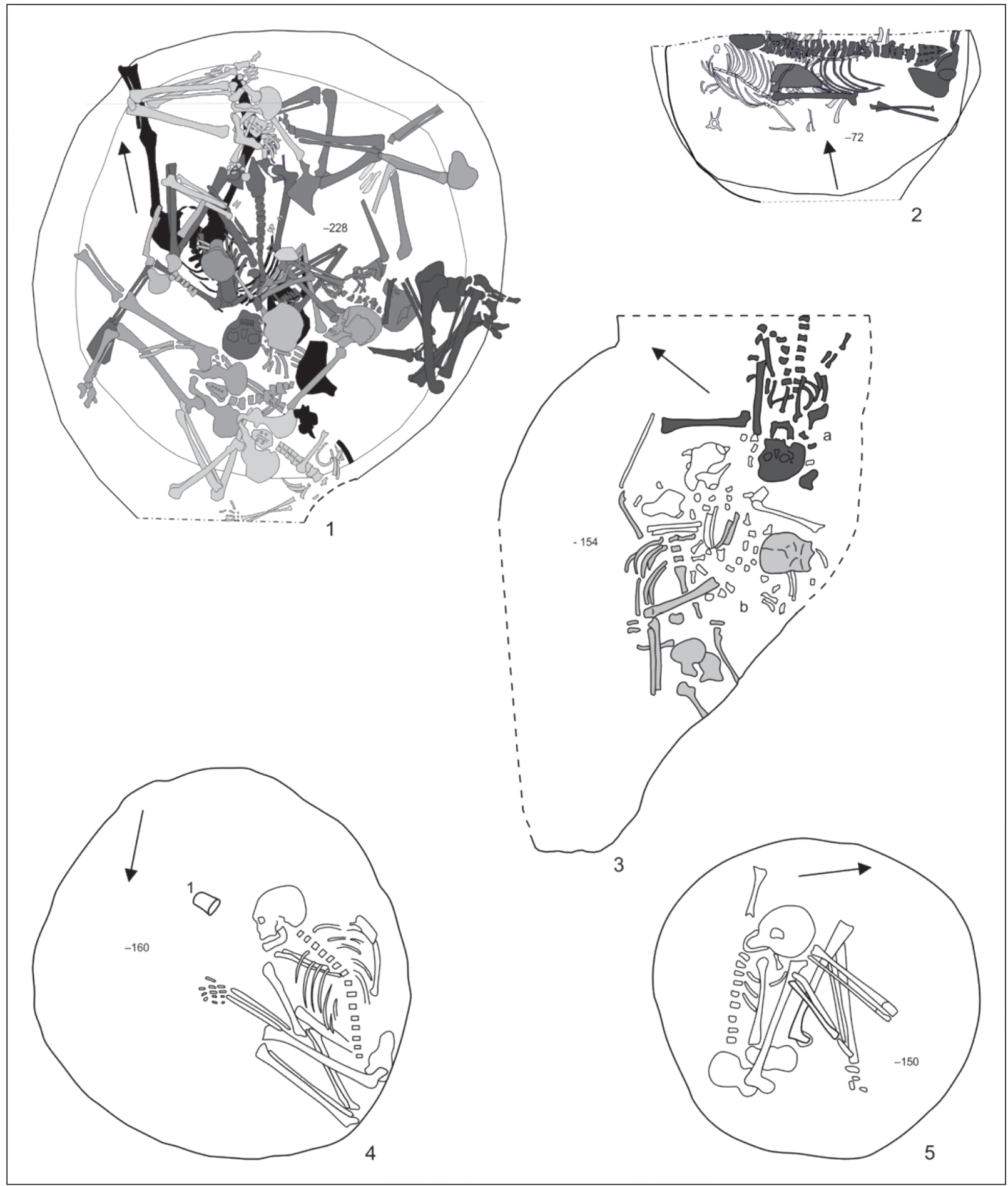

Obr. 2. 1-2 - Nitra-Staré Mesto (mestská tržnica; 1 - objekt A28; 2 - objekt C33, podla Bednár - Fottová 2003, obr. 3); 3 - Nitriansky hrad (Samova ulica, podla Bednár-Debnár 2019, 24); 4-5 - Nitra-Staré Mesto (Farská ulica; 4 - objekt 1; 5 - objekt 2, podl’a Hanuliak 1997, obr. 5).

Fig. 2. 1-2 - Nitra-Staré Mesto (mestská tržnica; 1 - feature A28; 2 - feature C33, acording Bednár - Fottová 2003, fig. 3); 3 - Nitriansky hrad (Samova ulica, acording Bednár-Debnár 2019, 24); 4-5 - Nitra-Staré Mesto (Farská ulica; 4 - feature 1; 5 - feature 2, acording Hanuliak 1997, fig. 5).

že by telá oboch osôb mohli byt' na úrovni terénu vystavené dlhodobejším dezartikulačným procesom a až následne odpratané do rôznych zásypových úrovní (porovnaj: Unger 2006, 152-154). 


\section{4. Územie historickej Nitry}

Zaujímavý vklad do riešenej problematiky poskytujú sídliskové objekty spracúvanej kategórie preskúmané v nitrianskej sídliskovej aglomerácii. Tento najvýznamnejší predurbánny útvar sformovaný vo východnej časti vel’komoravského územia chránil dômyselne vybudovaný obranný systém. K jeho poprednému postaveniu prispeli územno-správne, rezidenčné, cirkevno-organizačné funkcie doplnené značným hospodárskym potenciálom a zhustenou siet’ou najvýznamnejších krajinských ciest doplnených dialkovou komunikáciou (Ruttkay - Bednár 2014, 52-56; Lukačka 2002, 209; Ruttkay 2005, 78). Vzhl’adom k týmto okolnostiam i nadmernej koncentrácii žijúcich obyvatelov sa nezdá byt' dostatočne reprezentatívna celková početnost' tejto kolekcie zastúpená šiestimi sídliskovými objektmi zo štyroch rozdielnych polôh. Tesné spolužitie príslušníkov z najrôznejších sociálnych vrstiev poskytovalo akiste dostatočne pestrú škálu príležitostí ul’ahčujúcich ich marginalizáciu. K nim treba takisto pripojit' násilné činy, bojové strety rôzneho druhu, vrátane devastačného plienenia (Ruttkay, A. 2002, 107-108), ku ktorým dochádzalo prednostne v najvýznamnejších sídliskových útvaroch (Krejsová - Vacbút - Hejhal 2012, 390-391).

$\mathrm{S}$ jednou z možných lokálnych bojových akcií treba zrejme spojit’ náhle ukončenie existencie agrárneho sídliska odkrytého v priestoroch dnešnej mestskej tržnice ležiacej v južnej časti dnešného Starého Mesta. K zánikovému horizontu nesporne patria dve obilné zásobnice so skeletmi ludí a chovaných zvierat. Signifikantným svedectvom je objekt A28 (obr. 2: 1). Okrem psa bolo do jeho vnútra bez akýchkolvek úprav vhodených osem dospelých jedincov oboch pohlaví. Ich skelety neboli oddelené separačnou vrstvou zeminy. I preto sa ich zástupcovia navzájom prekrývali, viaceré kosti odlišných jedincov sa prelínali a st’ažovali ich identifikáciu. Zo situačného plánu taktiež vyplynulo, že nešlo o kompletne zachované telá s hlavou. Časté boli osamotené lebky, nekompletné postkraniálne skelety, oddelené končatiny a rozpojené samostatné kosti. $\mathrm{V}$ čiastočne zasypanom objekte C33 zasa zvyšky dvoch psov a hydiny doplnil skelet dospelej osoby (obr. 2: 2).

Opísaná situácia vznikla zrejme pri odpratávaní deštrukčných vrstiev z povrchovej úrovne pred d’alším využitím plochy na regulárne pochovávanie reprezentované ôsmimi hrobmi, zatial' čo nehrobové objekty boli iba dva. Od jeho počiatočnej etapy kladenej do prvých dvoch decénii 10. stor. a násilného zlikvidovania agrárneho sídliska mohlo ubehnút' nanajvýš 5 rokov (Bednár - Fottová 2003, 303-306; Bednár - Fottová - Zábojník 2002, 32-33). Z postrehnutej následnosti vyplynie teoreticky prípustné stotožnenie zánikového horizontu s akciou bavorských vojsk v roku 899. Ich oddiely vedené vojvodom Ljutpoldom a markgrófom Aribom mali vtrhnút' na územie nitrianskeho kniežatstva so zámerom vyslobodit' väzneného Svätopluka II., považovaného za chránenca cisára Arnulfa (Steinbübel 2004, 135, 147-151).

Naopak, pre chýbajúce relevantné pramene sotva dnes približime príčiny uloženia telesných zvyškov do objektu na Samovej ulici, tvoriacej okrajový úsek opevneného areálu z hradnej vyvýšeniny. Precíznejšie vymedzenie obvodových línií tohto objektu skomplikovala stratigrafická situácia kontaminovaná pravekým, včasnohistorickým osídlením a novovekým zásahom. Isté je, že na dno jamovitej priehlbne, prekrytej neskôr osamoteným hrobom z druhej polovice 9. stor., boli druhotne presunuté telesné zvyšky troch-štyroch zomrelých (obr. 2: 3; Bednár - Debnár 2019, 24). Z jedinca „a“ zo severovýchodného sektora sa zachovala chrbtica s lebkou, nekompletné kosti končatín boli presunuté, rebrá chýbajú. Jedinec „b“ z juhozápadného sektora má oddelenú lebku, kosti z hrudníka a končatín sú rozptýlené. Z priestoru medzi obomi skeletmi pochádzajú malé zlomky kostí i dlhé kosti z rozpojených končatín patriace jednému až dvom iným osobám. Analýza situačného plánu svedčí, že nejde o telá zomrelých, ale o nekompletné časti tiel rozpojené $s$ rôznou intenzitou na nespresnenom mieste terénneho povrchu.

Ako v prípade obilnice A28 z mestskej tržnice, tak aj z objektu na Samovej ulici nemohli byt' zomrelí pôvodne spríbuznení s príslušníkmi, ktorí odpratávali pozostatky zomrelých do nehrobového priestoru. A to s časovým odstupom a práve vtedy, ked’ si to vynútili objektívne skutočnosti. Podporné svedectvo poskytuje značne narušená kompaktnost' antropologického materiálu sotva dosiahnutel'ná iba v násilnom bojovom strete. Neprehliadnutel'né sú takisto chýbajúce prejavy pietnej úcty, ktoré sa v prípadoch štandardnej inhumácie uplatňujú nielen pri úprave hrobovej jamy i tiel blízkych osôb do rituálnej podoby, ale aj počas pohrebných obradov. V sledovanej situácii sa naopak prejavil opačný extrém. Zomrelí boli totiž na pochôdznej úrovni dlhodobo ponechaní napospas poveternostným vplyvom i nekontrolovatel’nému ohlodávaniu rôznymi zvieratami a až následne došlo k presunom telesných zvyškov do priehlbne.

Tretia lokalita s pertraktovaným typom sídliskových objektov leží takisto v rámci Starého Mesta na Farskej ulici. 
Vo výplni dvoch zásobnicových jám sa našli kompletné telá dospelých ležiace na l’avom boku resp. na pravom boku až hrudníku (obr. 2: 4-5). Horné a dolné končatiny sú výrazne až extrémne ohnuté. V objekte 1 ležala pred lebkou nízka keramická nádoba pohárovitej formy. $\mathrm{V}$ objekte 2 sa lebka ocitla v druhotnej polohe. Z dokumentačných záznamov nevyplynulo (Rajnic 1950) či k dislokácii došlo v rámci dutého priestoru alebo následkom jej zámerného oddelenia od krčnej chrbtice.

Okrem tohto momentu sa nezistili iné prejavy nepietnej manipulácie so zomrelými. Pri zvažovaní príčin vzniku oboch objektov sa zdá byt’ dôležitá pozícia lokality pri ceste smerujúcej do opevneného areálu na hradnom kopci. Nemôže íst' o náhodu, že násilne zaniknuté agrárnej sídlisko z priestoru dnešnej mestskej tržnice ležalo pri najvýznamnejšej dialkovej komunikácii smerujúcej cez Moravu do stredočeskej kotliny (Lukačka 2002, 208-209). Vo vel'komoravskom období patril tangovaný priestor do podhradia opevneného areálu „Vŕšok“ slúžiaceho ako predhradie hradiska z hradnej vyvýšeniny (Fusek 2008, 282, obr. 12).

Ako vo väčšine objektov z Mužle-Čenkova, tak aj u posledných dvoch reprezentantov z Farskej ulice v Nitre boli zrejme tieto osoby umiestnené do obilných zásobníc príslušníkmi miestnej komunity. Najmä pre nich nadobudla patričný význam dodatočná úprava tiel do pokrčenej polohy s pripisovanými obrannými účinkami. Vd’aka nej mohli pozostalí odstránit' vlastné obavy z poškodzovania ich každodenných aktivít proskribovanými indivíduami. V rovnakej miere sa dá u týchto zástupcov predpokladat’ marginalizácia ich niekdajšej bezúhonnej pozície. Príciny a okolnosti jej vzniku zostávajú neznáme, hoci násilie pri vojenskom prepade zostáva v trvalej platnosti.

Predchádzajúce interpretačné verzie sa dajú v plnom rozsahu uplatnit' v prípade dosial’ nespomenutej obilnice 126/81 preskúmanej na rozsiahlom vel'komoravskom sídlisku z Mikovho dvora, ktorý sa primkýna k južnému okraju dnešnej miestnej časti Chrenová. Z nadmerne stručného opisu možno iba vyčítat', že sa vo výplni tohto objektu zdokumentoval skelet dospelej ženy v ,silne pokrčenej polohe“ (Chropovský 2002, 51).

\section{Záver}

V príspevku boli zmapované signifikantnejšie príklady z vel'komoravských jamovitých objektov, ktoré mohli pôvodne súvisiet' s násilnými okolnost’ami sprevádzajúcimi bojové aktivity najrôznejšieho druhu. Uvádzané možnosti sú z logického pohl’adu akceptovatel’né. Čast' z nich nie je však v požadovanom rozsahu prijatel’ná, ked’že sa viaceré z predpokladaných okolností nepremietli do zhmotnenej archeologicky čitatel'nej podoby. Aj z tohto dôvodu sme stále zneistení pri interpretácii javov, ktoré v minulosti existovali, ale presvedčivejšie i jednoznačnejšie argumenty chýbajú. Očakávané svedectvo neposkytujú ani analýzy antropologického materiálu. Netreba azda pripomínat', že sa dosial' vyhodnotil obmedzený výsek z evidovaného fondu. Iba niektoré výsledky odbornej činnosti boli zverejnené. Prevažujú ústne poskytované informácie vychádzajúce z predbežne stanovených výsledkov. Napriek tomu okolnosti prispievajúce $\mathrm{k}$ marginalizácii a následnému umiestneniu niektorých jedincov do sídliskových objektov, uvedené v predchádzajúcom texte, zostávajú v platnosti. Ich hypotetické spojenie s násilnost’ami sprevádzajúcimi bojové akcie nestráca opodstatnenie. Menej presvedčivé sú informácie, podl’a ktorých by sa dali pochovaní pripojit’ k domácim ozbrojeným silám, k civilnej zložke miestnej komunity alebo k cudzích agresorom.

Poznámka: Štúdia vznikla s podporou projektu APVV-16-0449 - Stredoveká Nitra v hmotných prameňoch.

\section{Pramene}

Rajnič, A. 1956: Nálezová správa AÚ SAV 421/56. Nitra. 


\section{Bibiografia}

Bednár, P-Debnár, P. 2019: Záchranný archeologický výskum v Nitre na Samovej ulici. Archeologické výskumy a nálezy na Slovensku 2014, 24-25.

Bednár, P - Fottová, E. 2003: Nitra-tržnica - príspevok k poznaniu zázemia stredovekého mesta. Archaeologia historica 28, 303-315.

Bednár, P. - Fottová, E. - Zábojník, J. 2002: Výskum v priestore mestskej tržnice v Nitre. Archeologické výskumy a nálezy na Slovensku 2001, 32-33.

Bednárik, R. 1939: Príspevok k pohrebným zvykom slovenského l’udu. Národopisný sborník 1, 54-94.

Drozdová, E. - Parma, D. - Unger, J. 2005: Hromadný hrob obětí slovansko-mad’arského střetu v 9.-10. století u Brankovic. Archeologické rozhledy 57, 167-179.

Fusek, G. 2008: Die Nebenareale in der Struktur der großmährischen Burgstadt von Nitra. In: Boháčová, I. - Poláček, L. (Hrsg.): Burg - Vorburg - Suburbium. Zur Problematik der Nebenareale frühmittelalterlicher Zentren. Internationale Tagungen Mikulčice VII. Brno, 271-290.

Hanuliak, M. 1997: K problematike skeletov l’udských jedincov zo sídliskových objektov. Slovenská archeológia 45, 157-182.

Hanuliak, M. 2004: Vel’komoravské pohrebiská. Pochovávanie v 9.-10. storočí na území Slovenska. Nitra.

Hanuliak, M. 2011: Princípy porušovania zomrelých v 9. - 10. storočí na Slovensku. In: Stuchlík, S. (ed.): Materiály o pohřebním ritu. Druhotné zásahy v hrobech. Acta archaeologica Opaviensia 4. Opava, 125-139.

Hanuliak, M - Kuг̣ma, I. 2015: Mužla-Čenkov II. Osídlenie z 9. - 13. storočia. Nitra.

Hanuliak, M-Kužma, I. - Kolena, B. 2012: Kategorizácia jedincov pochovaných v opevnenom sídlisku 9. - 10. storočia v Mužle-Čenkove. Sborník Národního muzea v Praze, řada A - Historie 66, 71-80.

Cheben, I-Ruttkayová, J - Ruttkay, M. 1994: Výskumy na trase ropovodu vo Vel'kom Cetíne. Študijné zvesti AÚ SAV 30, 177-241.

Chropovský, B. 2002: Bola v Nitre na Mikovom dvore pochovaná slovenská princezná? In: Almanach Nitra 2002. Nitra, 49-53.

Jágerová, M. 2001: Slovenský pohreb. In: Botík, J. (ed.): Obyčajové tradície pri úmrtí a pochovávaní na Slovensku s osobitným zretel'om na etnickú a konfesionálnu mnohotvárnost'. Bratislava, 13-31.

Krejsová, J. - Vachút, P. - Hejhal, P. 2012: Válečné konflikty v raně středověkých Čechách a na Moravě. In: Dzieduszicki, W. - Wrzesziński, J. (ed.): Epidemie, klęski, wojny. Funeralia Lednickie, Spotkanie 10. Poznań, 385-412.

Krumphanzlová, Z. 1964: Zvláštnosti ritu na slovanských pohřebištích v Čechách. Vznik a počátky Slovanů 5, $177-212$.

Krumphanzlová, Z. 1971: Počátky křest’anství v Čechách ve světle archeologických pramenů. Památky archeologické 62, 406-437. 
Lesák, B. - Musilová, M. 1999: Hrobové celky z druhej polovice 9. až prvej polovice 10. storočia na území ŠMPR Bratislava. Studia archaeologica slovaca mediaevalia 2, 33-61.

Lukačkea, J. 2002: Cestná siet' v Nitre a v jej najbližšom okolí v 13. a 14. storočí. In: Marsina, R. (zost.): Nitra v slovenských dejinách. Martin, 208-211.

Maielo, G. 2014: Vampyrismus a Magia posthuma. Vampyrismus v kulturních dějinách Evropy. Praha.

Pollex, A. 2000: Betrachtungen zu jungslawischen Mehrfachbestattungen. Ethnographisch-archäologische Zeitschrift 41, 407-422.

Ruttkay, A. 2002: Odraz politicko-spoločenského vývoja vo vel'komoravskom vojenstve a výstroji. In: Ruttkay, A Ruttkay, M. - Šalkovský, P. (ed.): Slovensko vo včasnom stredoveku. Nitra, 105-121.

Ruttkay, A. 2005: Sídla spoločenských elít na strednom Ponitrí v 9. - 13. storočí. In: Ruttkay, M. (ed.): Dávne dejiny Nitry a okolia vo svetle najnovších archeologických nálezov. Nitra, 77-95.

Ruttkay, M. - Bednár, P. 2014: Nitra. Významné mocenské centrum Vel’kej Moravy. Historická revue 25/12. 51-57.

Steinbübel, J. 2004: Nitrianske kniežatstvo. Počiatky stredovekého Slovenska. Bratislava.

Točke, A. 1992: Materiály k dejinám južného Slovenska v 7. - 14. storočí. Študiné zvesti AÚ SAV 28, 5-248.

Unger, J. 2006: Pohřební ritus v 1. až 20. století v Evropě z antropologicko-archeologické perspektivy. In: Malina, J. (ed.): Panoráma biologické a sociokulturní antropologie 25, Brno.

Unger, J. 2008: Epidemie a války 9. až 20. stol. v archeologických nálezech lidských pozůstatků a ostatků Moravy a Slezska. In: Dzieduszicki, W. - Wrzesziński, J. (ed.): Epidemie, klęski, wojny. Funeralia Lednickie, Spotkanie 10. Poznań, 129-138.

Vallašek, A. 1972: Hromadný hrob z 10. storočia v Bratislave. Monumentorum Tutela-Ochrana pamiatok 8, 229252.

van Dülmen, R. 1999: Kultura a každodenní život v raném novověku (16. - 18. stoletî). Praha.

Zábojnik, J. 1985: Výskum včasnostredovekého pohrebiska v Cíferi-Páci. Študijné zvesti AÚ SAV 21, $205-216$.

\section{Summary}

The body remains, deposited in inferior way in pit-like features placed outside regular cemeteries, offer the testimony about the marginal social position of some of the deceased. Known examples of this kind from Slovakia were considered to be the stronger expressions of defensive practices applied towards particularly dangerous individuals. Unnatural positions of body remains with missing grave inventory contributed to completion of this image. Sites with greater amount of features with several individuals in their filling and with exceptionally preserved expressions of violent destruction of this settlement drawn attention to indistinctness of this theory. This breaking point happened with the help of fatal results of fight actions with the violence of such intensity which could have moved before that impeccable inhabitants to marginalised position towards other surviving relatives. It is not surprising that, with the influence of mutually interconnected crises moments, such affected individuals could not have been 
buried in standard way on necropolis of local community. Proscribed individuals were laid into the inferior space of settlement features as a consequence of this events. Their bodies were arranged to the flexed position (fig. 1:2, 5; $: 4,5$ ), prone position (fig. 1:3), their anatomical position was disturbed by intentional intervention (fig. 1:4) on behalf of protection of local community from their negative influence. Features, to which remains of bodies were thrown in quick sequence and without piety, not once also incomplete skeletons, are also not rare (fig. 1: 1; 2: 1-3). Aforesaid interpretation is acceptable from the logical point of view. Some of the cases from the other features are not so significant. Connection of individuals with local community, with home of hostile warriors remains only in hypothetical level. Results of specialized analysis of anthropologic material to confirm such bonds are missing. 